\title{
End-Users Housing Requirements in Tumfure Housing Estate in Gombe Metropolis, Nigeria
}

\author{
Dahiru Adamu ${ }^{1}$, Tafida Adamu Ibrahim ${ }^{1}$, Ibahim Abdullahi Sabo ${ }^{1}$, Iliyasu Ibrahim ${ }^{1}$ \\ ${ }^{1}$ Abubakar Tafawa Balewa University \\ Tawafa Belewa Way, P. M. B. 0248, Bauchi, 740272, Nigeria
}

DOI: $10.22178 /$ pos.68-3

JEL Classification: 018

Received 28.02.2021

Accepted 25.03.2021

Published online 31.03.2021

Corresponding Author:

lliyasu Ibrahim

iliyasuibrahim1515@gmail.com

(C) 2021 The Authors. This article

is licensed under a Creative

Commons Attribution 4.0

License @ (1)

\begin{abstract}
One of the critical success indicators of projects is to meet the requirements of end-users on which their satisfaction depend upon. This study aimed to examine end-users housing requirements in a Tumfure housing estate in Gombe metropolis, Nigeria, to improve end-user satisfaction. The study objectives were: To identify end-users housing requirements in Tumfure housing estate in Gombe metropolis. The survey design was used to collect responses from occupants of the estate using a structured questionnaire that produced a $65 \%$ response rate. The collected data was analysed using descriptive statistical tools of tables and means. The research found that end-users basic housing requirements in the Tumfure housing estate were the flow of natural ventilation and illumination, rooms suitable for a family unit, modern convenience, circulation spaces, and adequate security. The research recommended that end-users requirements and their peculiarities be the primary consideration in designing and developing public housing estate to ensure higher end-user residential satisfaction.
\end{abstract}

Keywords: end-users; housing requirement; housing estate; satisfaction and post occupancy.

\section{INTRODUCTION}

Housing encompasses the totality of the environment and infrastructure that provide shelter, human comfort, enhance people's health and productivity, and enable them to sustain their psycho-social or psycho-pathological balance in their environment [2]. Public housing is "a form of housing tenure in which the property is owned by a government authority, which may be central or local. The Nigerian government's effort to provide public housing dates back to the colonial era [15]. The public housing policy structure tends to favour the architect's preferences, with an overall target of low costing, while there is a need for the buildings to meet the people who use them [15]. Post Occupancy Evaluation (POE) was opined by [30] as a process of evaluating building performance in an organised and thorough way after it has been in occupation for some time. The term POE was said to have originated from occupancy permission given to certify that a property is fit for occupation [26].
As a suitable technique, POE involves a careful \& systematic approach to measuring a building's performance by involving each user group \& each critical element of the building under examination [18]. POE in this context is used to evaluate occupants experience with public housing developments. The experience was also defined by [16] as "anything that emerges, coalesces, becomes a phenomenon or experiences out of the inner and outer stimuli that simultaneously impinge on people".

Although residential quality studies have gained increasing attention in recent times, over the years, many housing estates were developed by both the Public and Private sectors or a partnership of both in Nigeria. In addition to that, such housing estate developments were insufficient in terms of demands; do not reflect end-users requirements; in most cases, affordable but not qualitative; affected by insufficient electricity (power) and water supply for residential consumption etc. [31]. Some reasons may be ad- 
duced on why buildings perform poorly in meeting users' needs and expectations. The major among them is the lack of adequate knowledge of users' changing needs and preferences by architects and other professionals who design, construct and maintain buildings.

There is a problem between the built environment professionals' design decisions and the building's performance and functionality as perceived by those who use the building in light of the above. Based on those above, there is an inadequate evaluation of housing end-users requirements that will serve as a basis for guiding future housing estate development's design decision to meet the end users' requirements.

\section{LITERATURE}

Public housing is a form of housing provision that relies on public funds in providing housing to citizens. Due to the intricate nature and diversity of stakeholders involved in public housing provision, a considerable quantum of research efforts has been directed to various aspects of public housing. These include public housing policy, the institutional framework for providing and managing public housing, public housing finance, public housing schemes and their outcomes. This section of the thesis examines the different perspectives public housing has been studied to identify specific aspects the current study is focusing on and situating it within the context of an existing body of knowledge on the subject matter.

One of the significant issues currently engaging the attention of administrators, scholars, and practitioners in public housing across the globe is the different housing policy frameworks or systems and their outcomes in public housing provisions. Public housing policy, in this context, relates to comprehensive statements of intentions, ideas, strategies, guiding principles and philosophies put forward by government and international organisations to address housing challenges [23]. According to [33], housing policy is a set of minimum standards and core policy guidelines in housing delivery that ensure that critical bottlenecks are addressed and basic needs are met. The above definitions suggest that public housing policy consists of decisions and action plans for implementing public housing programmes to achieve set goals in the community.
Authors [8] identified three basic housing policy systems within the global context. These are liberal, corporatist and social democratic policy systems. In liberal regimes, such as the United Kingdom and Ireland, housing provision is controlled by the market, with the government providing subsidies to stimulate demand rather than supply. In contrast, in the corporatist system (e. g. Germany, Austria, Switzerland) government acts as an enabler rather than a provider. Still, it may act as a provider where households' capacity to address housing challenges is inadequate [8]. This is opposed to the social-democratic system such as in Sweden, where State intervention in housing promotes equity.

Based on these different public housing policy systems identified above, several studies $[7,12$, $24,33]$ examined what constitutes appropriate public housing policy and trends in the evolution of public housing policy. These studies' findings show no panacea for housing policy formulation, nor any globally accepted housing policy that best addresses local and national needs and conditions. Authors [33] notably suggested that appropriate housing policy should simultaneously address supply constraints (by getting more land, cheap credit and materials into the markets), increase effective demand (by granting secure claims and boosting employment and incomegenerating activities), and ensures that interaction of supply and demand is not disadvantageous to any groups or lead to a high cost of housing. Moreover, the consensus is that appropriate housing policy should provide a practical framework for continuous decision making and a platform for maximising options available to all socioeconomic groups in meeting their housing needs without discrimination. On trends in the evolution of public housing policy, the author [12] noted that top-down strategies had given way to market and people-centred solutions, processes, and approaches, emphasising institutional capacity building. Authors [33] identified three major phases in the evolution of global housing policy since the 1960 s to include:

Phase 1: Large scale public sector investment in mass housing production (e.g. direct construction of houses for the poor).

Phase 2: Aided self-help housing, e. g. upgrading, site-and-services and core housing

Phase 3: The enabling approach, which is the current global housing policy thrust, emphasising 
the contributions of all stakeholders in collaboration on housing provision.

Another perspective public housing has been studied is assessing the institutional framework for public housing provision and management. In this study's context, the institutional framework consists of a system of interacting and interdependent organisations designed by people for productive collaboration within established norms, rules and constitutions [21]. In formulating relevant policies, efficiently implementing and monitoring them, the institutional framework has been identified as one of the vital components in public housing provision [33]. Author [6] noted that in three of the five different perspectives performance of the public housing sector can be examined by looking at housing producers, housing finance institutions, and governments who constitute critical institutions in the housing process. For this reason, the formation, structure, sustenance of formal and informal institutions, their role as actors and intermediaries in public housing, and the consequences their interactions generate in diverse settings have continued to engage the attention of scholars in housing studies. Consequently, some studies $[1,11,27]$ had examined the institutional framework in public housing production and management in Developing Countries. These studies found that increasing housing challenges in many Developing Countries has a solid link to the inappropriate institutional framework.

Housing infrastructural provision refers to bringing into existence the basic amenities and services needed for a particular activity or pursuit. However, no nation can boast of significant development or an enhanced economy without providing the basic infrastructures for the citizens' well-being. The provision of adequate infrastructural facilities is not taken for granted in developed countries; however, it remains a significant challenge in developing countries, especially in Sub-Saharan Africa. The problem of housing has become an everyday discussion in all quarters of Africa's developing countries' public and private services [32].

It has become increasingly glaring that most urban populations live in a dehumanising housing environment while those who have access to average housing do so at an abnormal cost. Several authors have ascribed different definitions of the word infrastructure. Infrastructure is the basic physical and organisational structures needed for society's operation like industries, buildings, roads, bridges, health services, governance, etc. It is the enterprise or the products, services, and facilities necessary for an economy to function [22]. Infrastructures can generally be described as interconnected structural elements that provide a framework supporting an entire development structure. It is an essential term for judging a country, region, state, and individual's developments/status. The term typically refers to the technical structures that support a society, such as roads, water supply, sewers, national electrical grids, telecommunications, and so forth. It can be defined as "the physical components of interrelated systems providing commodities and services essential to enable, sustain, or enhance societal living conditions" [14]. Authors [5] argued that infrastructure helps individuals cope with the different dimensions of poverty. It follows, therefore, that whenever people are deprived of basic infrastructures, the result is impoverishment.

A house is an evolutionary product of man's civilisation and a perfect reflection of the social system that creates it. Succinctly put, it is an externally expressed three-dimensional geometric structure, physically projected on the geographic space, internally organised and subdivided into differentiated but highly inter-related and communicating functional space [4]. A house, as explained, can also be seen as a dwelling place for human habitation, whether a crude hut or an elaborate mansion. The degree of intrinsic architectural interest, a house, provides shelter and acts as a focal point for day-to-day living [3]. The physical characteristics depend on the climate and terrain available, building materials, technological skills, and cultural determinants as the owners' social status and economic resources. A house is more than just a dwelling. It is a source of identity and status and a demonstrator or both to the outside world. It may become identified with assembly for a more comprehensive family or lineage that occupies it daily. It may also be a location for a business that provides the necessities of life or for one that augments the primary income [3].

Housing, on the other hand, as explained earlier, is a decisive integral of spatial formation, balanced development, and ecological unit. It is one of the most critical needs in man's life. Housing which used to be regarded as mere shelter, is now much more than that; thus, in today's parlance, housing is the totality of the house and the 
environment in which it is situated and those infrastructural facilities which make a living in the convenient and safe [4].

The universality of the housing problem made the U.N declares the first Monday of October every year as World Habitat Day. On this day, it is expected that everyone reflects on the housing problems all over the world. It ponders over possible ways of solving these problems to housing the homeless and ensure healthy and decent housing for those living in substandard places. It has different meanings for different cultures, groups, and individuals. Author [29] sees housing as a strategic asset to man, irrespective of his/her socioeconomic status, colour, or creed. As such, there lies a passion and emotional attachment to housing in a traditional African setting. Nevertheless, despite the number of housing programmes and policies, Nigeria's housing production level is still at its lowest ebb.

Housing, therefore, is a fundamental product of every human effort irrespective of his or her financial standing. Provision of shelter is that passive and primary function of housing while its secondary function is creating an environment that is best suited to the way of life of a people; in other words, a social unit of space. Housing symbolises the family's social status to both the wider community and the nuclear family setting. Simultaneously, the quality and quantity of housing stock is a reliable barometer of measuring any nation's technology, culture, and civilisation level. It contributes to the general well-being of a people, race or community [13]. When we use the word quality in this study, its usage is on a broad base, encompassing various meanings defined by researchers in almost all fields. A house's quality determines the reference as home if it performs some fundamental function for the residents. A house with all its necessary physical attributes must have a rich set of evolving cultural, demographic and psychological meanings attached to it to be called a home.

The following attributes [19] have been identified as relevant dimensions of a house to transform into a home: order, haven, identity, warmth, connectedness, and physical suitability, as further expatriated below.

1. A home helps to know our place in the world. It is a centre from which we venture and return; it is one way to order our world's existence. This ordering is not only spatial but temporal. Home is strongly related to our sense of continuity.
2. A home is a haven that surrounds us with privacy, security, refuge, and protection from the slings and arrows of life outside it.

3. A home is central to our identity. As social creatures, the home includes for us a sense of family or kinship, ethnic belonging, and socioeconomic status. Home is thus an essential part of who we are. Through self-expression and personalisation, the home comes to resemble or represent ourselves. We give the physical structure as we transform it from a mere residence into a home.

4. There is warmth in a home. It grows out of the preceding qualities but goes beyond them. The warmth is like that of a hearth but is symbolic and interpersonal.

5. Home means connectivity because the spatial and temporal order pattern helps us feel connected to certain people, the place, the past, and the future. We feel part of a family or group and part of a culture.

6. Home is physically suitable. This means more than the material physical aspects of the house. It means the form and structures of the house match our social and psychological needs.

The absence of the above components in a house will lead to diverse behavioural responses, including transformation through adaptive changes, to reach satisfaction with the dwelling.

\section{METHODOLOGY}

The study adopted exploratory and descriptive design because it will use objective methods to uncover its background and problems. The study approach considered most appropriate for this study is quantitative as numerical data will be collected and analysed. A survey research strategy that uses a questionnaire as an instrument of data collection was adopted in this research. This study evaluates, or explores, features and attributes that may improve future housing developments of end-users housing requirements. Therefore, the study will focus on the POE of Tumfure Housing Estate of 500 units of mix 2and 3-bedroom semi-detached bungalow and one-bedroom blocks of flat. The housing Estate is located along Gombe - Bauchi between Tumfure and Lafiyawo settlement at about $5 \mathrm{~km}$ from Gombe City Centre. The site covers an area of 20.72 hectares. The POE will be based on the perspective of the residents of 'Tumfure' housing estate. 


\section{RESULTS AND DISCUSSION}

Descriptive statistics based on the mean ranking was carried out to explore the facilities that endusers required most in Tumfure housing estate, Gombe State, Nigeria. The results in Table 1 showed the ranking, mean and standard deviation for each Item.

Table 1 - End-Users Housing Requirements

\begin{tabular}{|l|c|c|c|}
\hline Housing requirements & Mean & $\begin{array}{c}\text { Std. } \\
\text { Deviation }\end{array}$ & Rank \\
\hline $\begin{array}{l}\text { Flow of natural } \\
\text { ventilation \& } \\
\text { illumination }\end{array}$ & 3.0357 & 0.8517 & 1 st \\
\hline $\begin{array}{l}\text { Rooms suitable for the } \\
\text { family unit }\end{array}$ & 2.8705 & 0.8150 & 2nd \\
\hline $\begin{array}{l}\text { Modern convenience } \\
\text { (toilet \& bathroom }\end{array}$ & 2.8143 & 0.9023 & 3rd \\
\hline $\begin{array}{l}\text { Circulation space } \\
\text { (courtyard, veranda, } \\
\text { etc.) }\end{array}$ & 2.6857 & 0.9677 & 4 th \\
\hline $\begin{array}{l}\text { Adequate security } \\
\text { (doors \& windows) }\end{array}$ & 2.4571 & 0.8845 & 5 th \\
\hline Estate perimeters & 2.4143 & 0.8975 & 6 th \\
\hline $\begin{array}{l}\text { Ceiling covering that } \\
\text { meets thermal } \\
\text { requirements }\end{array}$ & 2.4071 & 0.8388 & 7 th \\
\hline $\begin{array}{l}\text { Ease of communication } \\
\text { within a building }\end{array}$ & 2.4000 & 0.8293 & 8th \\
\hline $\begin{array}{l}\text { Adequate house } \\
\text { functional units }\end{array}$ & 2.3857 & 0.9250 & 9th \\
\hline $\begin{array}{l}\text { Internal/external } \\
\text { aesthetics }\end{array}$ & 2.3643 & 0.7976 & 10 th \\
\hline Garage/car park & 2.0929 & 0.9127 & 11 th \\
\hline Adequate road network & 2.0714 & 0.7924 & 12 th \\
\hline Water \& storage facility & 2.0429 & 0.8290 & 13 th \\
\hline $\begin{array}{l}\text { Public power supply } \\
\text { with a modern metering } \\
\text { system }\end{array}$ & 1.7929 & 0.7247 & 14 th \\
\hline $\begin{array}{l}\text { Adequate waste } \\
\text { management }\end{array}$ & 1.7643 & 0.8277 & 15 th \\
\hline $\begin{array}{l}\text { Landscape in an entire } \\
\text { housing estate }\end{array}$ & 1.7500 & 0.6361 & 16 th \\
\hline Recreational facilities & 1.5714 & 0.6586 & 17 th \\
\hline $\begin{array}{l}\text { Households shopping } \\
\text { facilities }\end{array}$ & 1.4071 & 0.5730 & 18 th \\
\hline Health care facilities & 1.4000 & 0.5852 & 19 th \\
\hline $\begin{array}{l}\text { Automated teller } \\
\text { machine (ATM) }\end{array}$ & 0.3960 & 20 th \\
\hline
\end{tabular}

Table 1 shows the end-users housing requirements in the Tumfure housing estate. It shows that the housing elements the required most, based on the five-point measurement scale, are flow of natural ventilation and illumination, rooms suitable for the family unit, modern convenience, circulation spaces and adequate security with mean values of $3.0357,2.8705,2.8143$, 2.6857 and 2.4571 ranked 1 st to 5 th respectively. The least required housing elements were automated teller machine, health care facilities, shopping facilities and landscaping with mean values of $1.0929,1.4,1.4071,1.5714$ and 1.75 and ranked 20th, 19th, 18th, 17th, and 16th, respectively in order of preference. Estate perimeters, ceiling covering that meets thermal requirements, ease of communication within the building, adequate house functional units, internal/external aesthetics, garage/park, good road network, and water and storage facilities, public power supply with modern metering system and adequate waste management were ranked 6 th to 15 th housing requirements by end-users in order of preference. Generally, end-users level of housing elements requirements was average, as indicated by 2.14 mean values.

However, information on end-users housing requirements was solicited from the respondents using a Likert scaled questionnaire. Respondents were asked to score their level of requirement of the housing elements variables on the Likert scale rating from 1-5 from very low to very high. The research outcome shows that the end-users housing elements required most, based on a fivepoint measurement scale, are flow of natural ventilation and illumination, rooms suitable for the family unit, modern convenience, circulation spaces, and adequate security ranked 1st to 5th, respectively. This result contradicts the results of [14] in their studies. The most substantial reason may be due to differences in the locations and periods of the researches. However, it is in agreement with that of [17].

Estate perimeters, ceiling covering that meets thermal requirements, ease of communication within the building, adequate house functional units, internal/external aesthetics, garage/park, good road network, and water and storage facilities, public power supply with modern metering system and adequate waste management were ranked 6th to 15 th housing requirements by endusers in order of preference. This result is in line with $[17,25,28,29]$. However, research conducted by [14] does not consider internal/external aesthetics as end-users housing requirement. The difference may be due to differences in geographical locations and the research context. 
However, the least required housing elements were automated teller machine, health care facilities, shopping facilities and landscaping and ranked 20th, 19th, 18th, 17th, and 16th, respectively, in order of preference. These are environmental and neighbourhood amenities that make the estate functional. This may be contrary to the suggestions of [20] that public estate requires a basis of public infrastructure. This result shows that Tumfure housing estate end users are more concerned with house elements than neighbourhood amenities and services.

Therefore, a questionnaire was sent to potential respondents to reveal their opinions. The ten most essential housing requirements of endusers in Tumfure housing estate were confirmed based on their average mean values.

The flow of natural ventilation and illumination, rooms suitable for the family unit, modern convenience, circulation spaces and adequate security ranked first to fifth. Estate perimeters, ceiling covering that meets thermal requirements, ease of communication within the building, adequate house functional units, internal/external aesthetics, garage/park, good road network, and water and storage facilities, public power supply with modern metering system and adequate waste management were ranked six to fifteen housing requirements by end-users in order of preference. However, the least required housing elements were automated teller machine, health care facilities, shopping facilities and landscaping and ranked twenty, nineteen, eighteen, seventeenth, and sixteenth, respectively, in order of preference. These are environmental and neighbourhood amenities that make the estate functional.

\section{CONCLUSION}

This research examined the end-users housing requirement in Tumfure housing estate Gombe to suggest ways of improving end-users housing satisfaction.

The research found that end-users basic housing requirements in the Tumfure housing estate were the flow of natural ventilation and illumination, rooms suitable for the family unit, modern convenience, circulation spaces, and adequate security.

This is followed by Estate perimeters, ceiling covering that meets thermal requirements, ease of communication within the building, adequate house functional units, internal/external aesthetics, garage/park, good road network, and water and storage facilities, public power supply with modern metering system and adequate waste management. The least required housing elements were automated teller machine, health care facilities, shopping facilities and landscaping.

The study recommended that developers of the public estate emphasise the flow of natural ventilation and illumination, rooms suitable for the family unit, modern convenience, circulation spaces, and adequate security to meet the housing estates' end-users requirements.

Similarly, emphasis should also be given to Estate perimeters, ceiling covering that meets thermal requirements, ease of communication within the building, adequate house functional units, internal/external aesthetics, garage/park, good road network, and water and storage facilities, public power supply with modern metering system and adequate waste management.

\section{REFERENCES}

1. Ademiluyi, A. I., \& Raji, B. A. (2008). Public and private developers as agents in urban housing delivery in Sub-Saharan Africa: The situation in Lagos State. Humanity \& Social Sciences Journal, 3(2), 143-150.

2. Afolayan, S. A. (2007). Private Sector Driven Housing Delivery. Akoka: University of Lagos.

3. Ahsen, O., \& Gulcin, P. G. (2005). Space use, dwelling layout and housing quality: an example of lowcost housing in Istanbul. Retrieved from https://www.researchgate.net/publication/27250427_SPACE_USE_DWELLING_LAYOUT_AND_ HOUSING_QUALITY_AN_EXAMPLE_OF_LOW-

COST_HOUSING_IN_ISTANBUL_in_Housing_Space_and_Quality_of_Life

4. Ajanlekoko, J. S. (2001, October 2-5). Sustainable housing development in Nigeria - The financial and infrastructural implication. Retrieved from

https://www.fig.net/resources/proceedings/2001/nairobi/ajanlekoko-CMWS1-1.pdf 
5. Amis, P., \& Kumar, S. (2000). Urban economic growth, infrastructure and poverty in India: lessons from Visakhapatnam. Environment and Urbanization, 12(1), 185-196. doi:

10.1177/095624780001200113

6. Arimah, B. C. (2000). Housing-sector Performance in Global Perspective: A Cross-city Investigation. Urban Studies, 37(13), 2551-2579. doi: 10.1080/00420980020080691

7. Awotona, A. (1987). Housing policy in Nigeria. Habitat International, 11(2), 89-103. doi: 10.1016/0197-3975(87)90059-2

8. Balchin, P. N., \& Stewart, J. (2001). Social housing in Latin America: Opportunities for affordability in a region of housing need. Journal of Housing and the Built Environment, 16(3), 333-341. doi: 10.1023/A:1012520013862

9. Bayode, A. O. (2008). Towards the involvement of youths in housing provision in Nigeria. International NGO Journal, 3(6), 104-107.

10. Brown, M., Cummings, C., Lyons, J., Carrión, A., \& Watson, D. P. (2018). Reliability and validity of the Vulnerability Index-Service Prioritization Decision Assistance Tool (VI-SPDAT) in real-world implementation. Journal of Social Distress and the Homeless, 27(2), 110-117. doi: 10.1080/10530789.2018.1482991

11. Chukwujekwu, I. E. (2005). The Role of Housing Corporations in Housing Delivery: A case Study of Kogi Investment and Properties Ltd. The Journal of the Association of Housing Corporations of Nigeria, 1(9), 6-9.

12. Erguden, S. (2001, October 2-5). Low-cost housing: policies and constraints in developing countries. Retrieved from https://www.fig.net/resources/proceedings/2001/nairobi/erguden-CMTS11.pdf

13. Franklin, B. J. (2001). Discourses of Design: Perspectives on the Meaning of Housing Quality and? Good? Housing Design. Housing, Theory and Society, 18(1-2), 79-92. doi: $10.1080 / 140360901750424789$

14. Fulmer, J. E. (2009). What in the world is infrastructure? Retrieved from https://30kwe1si3or29z2y020bgbet-wpengine.netdna-ssl.com/wpcontent/uploads/2018/03/what-in-the-world-is-infrastructure.pdf

15. Geller, A. C., Rees, V. W., \& Brooks, D. R. (2016). The Proposal for Smoke-Free Public Housing. JAMA, 315(11), 1105. doi: 10.1001/jama.2016.1380

16. Hurlburt, R. T. (2011). Describing inner experience? Proponent meets skeptic. Cambridge: Mit Press.

17. Iyer, K. C., \& Jha, K. N. (2005). Factors affecting cost performance: evidence from Indian construction projects. International Journal of Project Management, 23(4), 283-295. doi: 10.1016/j.ijproman.2004.10.003

18. Khan, S., \& Kotharkar, R. (2012). Performance Evaluation of School Environs: Evolving an Appropriate Methodology Building. Procedia - Social and Behavioral Sciences, 50, 479-491. doi: 10.1016/j.sbspro.2012.08.052

19. Mira, G. R., Uzzell, D., Real, J. E., \& Romay, J. (2005). Housing, space and quality of life. Routledge.

20. Morakinyo, K. O., Okunola, A. S., Musibau, L., Odewande, A. G., \& Dada, O. (2014). An assessment of housing infrastructural provision in public housing: a case study of bashorun housing estate Akobo, Ibadan Oyo State, Nigeria. Civil and Environmental Research, 6(12), 102-113.

21. Odusote, B., \& Akinola, T. (2017). Design and Implementation of an E-deliberation System Case Study. Retrieved from http://eprints.covenantuniversity.edu.ng/9820/1/6.\%20CUCEN\%202017\%20E-Deliberation\%20System.pdf

22. Olanrewaju, A., Woon, T.C. (2017). An exploration of determinants of affordable housing choice. International Journal of Housing Markets and Analysis, 10(5), 703-723. doi: 10.1108/IJHMA-112016-0074 
23. Omole, F. K. (2001). Basic issues in housing development. Ondo: FemoBless Publications.

24. Onibokun, A. G. (1985). Housing in Nigeria. Ibadan: Nigerian Institute for Social and Economic Research.

25. Poon, C. S., Yu, A. T. W., Wong, S. W., \& Cheung, E. (2004). Management of construction waste in public housing projects in Hong Kong. Construction Management and Economics, 22(7), 675-689. doi: $10.1080 / 0144619042000213292$

26. Riley, M., Kokkarinen, N., \& Pitt, M. (2010). Assessing post occupancy evaluation in higher education facilities. Journal of Facilities Management, 8(3), 202-213. doi: 10.1108/14725961011058839

27. Rondinelli, D. A. (1990). Housing the Urban Poor in Developing Countries. American Journal of Economics and Sociology, 49(2), 153-166. doi: 10.1111/j.1536-7150.1990.tb02269.x

28. Saleh, N., Kim, H.-J., Phenrat, T., Matyjaszewski, K., Tilton, R. D., \& Lowry, G. V. (2008). Ionic Strength and Composition Affect the Mobility of Surface-Modified Fe0Nanoparticles in Water-Saturated Sand Columns. Environmental Science \& Technology, 42(9), 3349-3355. doi: 10.1021/es071936b

29. Samson, M., \& Lema, N. M. (2002, November). Development of construction contractors performance measurement framework.

30. Shen, Y., \& Chai, Y. W. (2012). Study on commuting flexibility of residents based on GPS data: A case study of suburban mega-communities in Beijing. Acta Geographica Sinica, 67(6), 733-744.

31. Uba, B. V., Aliyu, A., Abubakar, A., Uba, S. A., Gidado, S., Edukugho, A., ... Nguku, P. (2016). Knowledge and prevalence of Human African Trypanosomiasis among residents of Kachia grazing reserve, Kachia local government area, Kaduna state, Nigeria, 2012. Pan African Medical Journal, 23. doi: 10.11604/pamj.2016.23.89.7999

32. Udoka, I. S. (2013). The Imperatives of the Provision of Infrastructure and Improved Property Values in Nigeria. Mediterranean Journal of Social Sciences. doi: 10.5901/mjss.2013.v4n15p21

33. UN-Habitat. (2006). State of the World's Cities 2006/7. New York: United Nations. 